\begin{tabular}{c} 
Tersedia online di: http://ejournal-balitbang.kkp.go.id/index.php/bawal \\
e-mail:bawal.puslitbangkan@ gmail.com \\
BAWAL WIDYA RISET PERIKANAN TANGKAP \\
Volume 10 Nomor 3 Desember 2018 \\
p-ISSN: 1907-8226 \\
e-ISSN: 2502-6410 \\
BAWAL \\
Nomor Akreditasi Kementerian RISTEKDIKTI: 21/E/KPT/2018 \\
\hline \hline
\end{tabular}

\title{
ASPEK BIOLOGI DAN KEBIASAAN MAKANAN IKAN CAKALANG (Katsuwonus pelamis) DI LAUT FLORES DAN SEKITARNYA
}

\section{BIOLOGICAL ASPECTS AND FOOD HABITS OF SKIPJACK TUNA (Katsuwonus pelamis) IN FLORES SEA AND ADJACENT WATERS}

\author{
Yoke Hany Restiangsih" ${ }^{* 1}$ dan Khairul Amri ${ }^{1}$ \\ ${ }^{1}$ Peneliti pada Balai Riset Perikanan Laut - Jl. Raya Bogor KM 47, Nanggewer- Cibinong, Bogor, Jawa Barat, Indonesia \\ Teregistrasi I tanggal: 14 Desember 2017; Diterima setelah perbaikan tanggal: 07 Agustus 2018; \\ Disetujui terbit tanggal: 28 September 2018
}

\begin{abstract}
ABSTRAK
Cakalang (Katsuwonus pelamis) merupakan ikan yang memiliki nilai ekonomis penting dan banyak tertangkap dengan huhate di perairan Laut Flores dan sekitarnya. Tujuan Penelitian adalah mengkaji beberapa aspek biologi ikan cakalang yang didaratkan di Pangkalan Pendaratan Ikan (PPI) Amagarapati dan unit pengolahan ikan (UPI) di Larantuka pada bulan Februari sampai Oktober 2015. Hasil penelitian menunjukkan ukuran panjang cagak berkisar antara $25-74 \mathrm{~cm}$ dengan modus pada nilai tengah $42 \mathrm{~cm}$. Pola pertumbuhan bersifat alometrik positif dan nisbah kelamin jantan terhadap betina sebagai 1:1,14. Awal musim pemijahan berlangsung pada FebruariMaret dan Juli-Agustus. Ukuran pertama kali ikan tertangkap (Lc) pada panjang 48,8 cmFL lebih besar dengan panjang pertama kali matang gonad (Lm ) 41,1 cmFL, diduga perikanan cakalang di Larantuka mengarah pada recruitment overfishing. Kebiasaan makan ikan cakalang bersifat karnivora dengan komposisi $55,7 \%$ ikan tembang (Sardinella spp); 34,7\% ikan teri (Stelophorus spp); 7,9\% ikan layang (Decapterus spp); 0,9\% cumi-cumi (Loligo sp); 0,7\% berupa hancuran ikan yang sudah tidak dapat diidentifikasi jenisnya dan sebesar 0,1\%, berupa krustasea.
\end{abstract}

Kata Kunci: Biologi; kebiasaan makanan; Katsuwonus pelamis; Laut Flores

\section{ABSTRACT}

Skipjack tuna (Katsuwonus pelamis) is one of caught by pole and line in Flores Sea and adjacent waters. Research was conducted to study biological aspects of skipjack tuna based on monthly catches landed at Amagarapati fishing port in Larantuka during February to October 2015. The results showed that fork length ranged from 25 to $74 \mathrm{~cm}$ with modus of $42 \mathrm{~cm}$ midlength. The growth pattern are alometric positive. The sex ratio of males to females was 1:1,14. The results showed that spawning seasons occured in February-March and July-October. Length at first capture (Lc) by pole and line was $48.8 \mathrm{cmFL}$ and length at first maturity (Lm) was $41.1 \mathrm{cmFL}$, this condition indicated recruitment overfishing in its fisheries. Food habits of skipjack tuna are carnivorous with composition 55,7\% Sardinella spp; 34,7\% Stelophorus spp; 7,9\% Decapterus spp; 0,9\% Loligo sp; 0,7\% flesh fish fragments that can't be identified; and 0,1\%, crustasea.

Keywords: Biology; Food habits; Katsuwonus pelamis; Flores Sea 


\section{PENDAHULUAN}

Penelitian aspek biologi suatu spesies ikan penting dilakukan sebagai pengetahuan dasar yang dibutuhkan dalam pengelolaan sumber daya. Salah satu sumber daya potensial yang pengamatan aspek biologinya masih sangat diperlukan untuk terus diperbarui, khususnya untuk jenis ikan yang hidup di perairan oseanik, adalah sumber daya ikan cakalang (Katsuwonus pelamis).

Ikan cakalang atau yang biasa disebut skipjack tuna merupakan highly migratory species yang distribusinya cukup luas, mencakup perairan tropis hingga ke perairan sub tropis (Collette \& Nauen, 1983). Untuk perairan Indonesia, Laut Flores merupakan salah satu habitat penting ikan ini dan sudah dimanfaatkan nelayan sejak lama (Anonimus, 2015). Ikan cakalang banyak tertangkap huhate (pole and line), baik menggunakan alat bantu rumpon ataupun sistem hunting (mencari gerombolan) dan hasil tangkapannya didaratkan di Kota Larantuka.

Huhate tergolong alat tangkap pancing yang terdiri dari joran atau bambu, tali pancing dan mata pancing. Alat ini banyak digunakan di Larantuka dan dalam pengoperasiannya huhate dibantu rumpon. Alat ini dikhususkan untuk menangkap ikan cakalang sehingga sering disebut pancing cakalang (Diniah et al., 2001). Pada kenyataannya penangkapan dengan alat tangkap huhate sering juga tertangkap jenis ikan lain seperti tuna, tongkol dan lainnya (Akbar et al., 2016).

Sumberdaya ikan cakalang tersebar cukup luas di perairan Indonesia. Total hasil tangkapan ikan pelagis besar di Indonesia tahun 2005-2014, didominasi oleh cakalang sebesar $29,6 \%$, sisanya berupa ikan tongkol komo $(12,4 \%)$, tongkol krai $(12,3 \%)$, madidihang $(11,6 \%)$, tongkol abu-abu $(8,7 \%)$, serta ikan pelagis besar lainnya sekitar 15\% (Anonimus, 2015). Untuk menjaga kelestarian sumberdaya ikan cakalang diperlukan strategi pengelolaan salah satunya dari aspek biologi.

Tulisan ini membahas aspek biologi ikan cakalang hasil tangkapan huhate di perairan Laut Flores, meliputi: distrubusi ukuran; pola pertumbuhan; rasio kelamin; tingkat kematangan gonad (TKG); dan kebiasaan makan. Hasil penelitian diharapkan dapat dimanfaatkan sebagai bahan masukan untuk pengelolaan sumberdaya ikan cakalang secara berkelanjutan.

\section{BAHANDANMETODE Waktu dan Lokasi Pengambilan Contoh}

Pengumpulan contoh ikan cakalang (Katsuwonus pelamis) dengan bantuan enumerator dilakukan di Pangkalan Pendaratan Ikan (PPI) Amagarapati dan salah satu UPI di Larantuka. Sebanyak 235 contoh dianalis dari hasil tangkapan huhate yang dioperasikan pada pagi dan sore hari. Pengamatan jenis kelamin, tingkat kematangan gonad dan kebiasaan makan dilakukan pada bulan Februari, Maret, April, Mei, Juli, Agustus dan Oktober 2015. Sampel ikan terpilih diukur panjang cagak (Fork length, $F L$ ) menggunakan papan ukur berketelitian $1 \mathrm{~mm}$ dan ditimbang beratnya dengan timbangan berketelitian 1,0 g. Pengamatan tingkat kematangan gonad dan isi lambung dilakukan di lapangan, kemudian diidentifikasi dan ditimbang beratnya menggunakan timbangan digital berketelitian $0.01 \mathrm{~g}$.

\section{Analisis Data \\ Hubungan Panjang-Bobot}

Hubungan panjang-bobot mengikuti hukum kubik, bahwa bobot ikan sebagai pangkat tiga dari panjangnya sesuai dengan persamaan dari Bal \& Rao (1984), yaitu: $W=a L^{b}$

$\log \mathrm{W}=\log \mathrm{a}+\mathrm{b} \log \mathrm{L}$

dimana;

$\mathrm{W}=$ bobot individu (gram)

$\mathrm{L}=$ panjang cagak $(\mathrm{cm})$

$\mathrm{a}=$ intercept (perpotongan antara garis regresi dengan sumbu y)

$\mathrm{b}=$ koefisien regresi (sudut kemiringan garis)

Dari persamaan tersebut dapat diketahui pola pertumbuhan ikan yaitu dengan cara melihat nilai b yang diperoleh :

a) Jika $b=3$, pertumbuhan bersifat isometrik, yaitu pertambahan panjang sama dengan pertumbuhan bobotnya,

b) Jika b>3, maka pola pertumbuhan bersifat allometrik positif, yaitu pertambahan bobot lebih cepat dari pertambahan panjangnya,

c) Jika b<3, maka pola pertumbuhan bersifat allometrik negatif, yaitu pertambahan panjang lebih cepat dari pertambahan bobotnya.

\section{Rata-rata Panjang Pertama Kali Tertangkap (Lc50\%) dan Panjang Pertama Kali Matang Gonad (Lm)}

Analisa rata-rata ukuran ikan pertama kali tertangkap (Lc) dilakukan dengan cara membuat grafik hubungan antara panjang ikan (sumbu $\mathrm{X}$ ) dengan jumlah ikan (sumbu Y) sehingga diperoleh kurva berbentuk sigmoid. Nilai Lc yang menggambarkan panjang pada $50 \%$ pertama kali tertangkap dihitung dengan persamaan (Jones, 1976 dalam Sparre \& Venema, 1999) :

$$
\begin{aligned}
& S_{L}{ }^{\text {stt }}=\frac{1}{1+\exp \left(S_{1}-S_{2} * L\right)} \\
& \operatorname{Ln}\left[\frac{1}{S L}-1\right]=S_{1}-S_{2} * L
\end{aligned}
$$




$$
L_{50 \%}=\frac{S 1}{S_{2}}
$$

Dimana;

SL $=$ kurva logistik (selektivitas alat tangkap berbasis panjang);

$\mathrm{S}_{1}$ dan $\mathrm{S}_{2}=$ konstanta a dan $\mathrm{b}$ pada rumus kurva logistik

Pendugaan panjang pertama kali matang gonad ( $\mathrm{Lm}$ ) dilakukan sesuai dengan prosedur penghitungan dari Spearman - Karber yang dilakukan oleh Udupa (1986) dalam Saputra (2005) sebagai berikut:

$\mathrm{m}=\mathrm{X}_{\mathrm{k}}+\mathrm{X} / 2-\left(\mathrm{X} \sum \mathrm{P}_{\mathrm{i}}\right)$

Tabel 1. Deskripsi tingkat kematangan gonad

Table 1. Description of gonado maturity stages dimana :

$\mathrm{m}=$ logaritma ukuran ikan saat pertama matang gonad

$\mathrm{Xk}=$ logaritma ukuran ikan dimana $100 \%$ ikan sampel sudah matang $\left(\mathrm{P}_{\mathrm{i}}=1\right)$

$\mathrm{X}=$ selisih logaritma ukuran nilai tengah panjang

$\mathrm{P}_{\mathrm{i}}=$ proporsi ikan matang pada kelompok ke-i

Rata-rata ukuran ikan pertama matang gonad diperoleh dari nilai antilog-m.

\section{Tingkat Kematangan Gonad (TKG)}

TKG diamati secara visual dengan cara melihat perubahan morfologi gonad. Perkembangan gonad dibagi menjadi lima stadium berdasarkan Holden \& Raitt (1974) sebagai berikut:

\begin{tabular}{|c|c|c|}
\hline $\begin{array}{c}\text { Tingkat } \\
\text { Kematangan } \\
\text { Gonad } \\
\text { (Maturity Stage) } \\
\end{array}$ & $\begin{array}{l}\text { Kategori } \\
\text { (Category) }\end{array}$ & Keterangan (Remarks) \\
\hline I & Belum matang/immature & $\begin{array}{l}\text { Ovarium dan testis sekitar } 1 / 3 \text { panjang rongga perut. Ovarium berwarna } \\
\text { merah jambu, transparan, sedangkan testis keputih-putihan dan telur tidak } \\
\text { dapat dilihat dengan mata telanjang. }\end{array}$ \\
\hline II & $\begin{array}{l}\text { Perkembangan/maturingvir } \\
\text { gin }\end{array}$ & $\begin{array}{l}\text { Ovarium dan testis sekitar } 2 / 3 \text { panjang rongga perut. Ovarium berwarna } \\
\text { merah jambu, jernih dan transparan, sedangkan testis berwarna keputihan, } \\
\text { bentuknya tidak simetris dan telur tidak dapat dilihat dengan mata telanjang. }\end{array}$ \\
\hline III & Pematangan/ripening & $\begin{array}{l}\text { Ovarium berwarna merah jambu, kekuningan dan terlihat butiran kecil, } \\
\text { sedangkan testis berwarna putih krem dengan telur transparan dan dapat } \\
\text { diamati dengan mata telanjang. }\end{array}$ \\
\hline IV & Bunting/matang/ripe & $\begin{array}{l}\text { Ovarium dan testis sekitar } 2 / 3 \text { sampai memenuhi rongga perut. Ovarium } \\
\text { berwarna coklat kemerahan, banyak diliputi pembuluh darah dan telur dapat } \\
\text { diamati dengan mata telanjang, sedangkan testis halus dan berwarna putih } \\
\text { agak krem. }\end{array}$ \\
\hline $\mathrm{V}$ & Memijah/spent & $\begin{array}{l}\text { Ovarium dan testis berkurang sampai } 1 / 2 \text { panjang rongga perut. Pada lapisan } \\
\text { dinding masih tersisa telur matang, sedangkan testis bertekstur lembek dan } \\
\text { pendek. }\end{array}$ \\
\hline
\end{tabular}

Tingkat kematangan gonad dianalisis dengan rumus GSI dari Afonso-Dias et al. (2005):

$$
I K G=\frac{G w}{W} x 100 \%
$$

$$
\text { dimana; }
$$

IKG = Indeks kematangan gonad

$\mathrm{Gw}=$ berat gonad (gram)

$\mathrm{W}=$ berat total (gram)

\section{Kebiasaan Makanan}

Evaluasi jenis makanan dengan menggunakan indeks bagian terbesar (index of preponderance) merupakan gabungan dari dua metode, yaitu metode frekuensi kejadian dan volumetrik. Metode ini dikembangkan oleh Natarajan \& Jhingran (1961) dalam Effendie (1979) dengan rumus:

$$
\operatorname{IPi}(\%)=\frac{v i \times o i}{\Sigma(v i \times o i)} X 100 \%
$$

Dimana;

$\mathrm{IPi}=$ indeks bagian terbesar (index of preponderance);

$\mathrm{V}=$ persentase volume satu macam makanan; $\mathrm{Oi}=$ persentase frekuensi kejadian satu macam makanan;

$\mathrm{Vi} * \mathrm{Oi}=$ jumlah $\mathrm{Vi}$ xOi dari semua macam makanan.

\section{HASIL DAN BAHASAN \\ Hasil}

\section{Struktur Ukuran}

Sebaran panjang cagak (fork length) sejumlah 235 ekor cakalang hasil tangkapan huhate yang dikumpulkan pada Februari-Oktober 2015 diperoleh kisaran antara 25 - 74 
cmFL dengan modus $42 \mathrm{cmFL}$. Distribusi ukuran panjang dapat dilihat pada gambar 1 .

\section{Hubungan Panjang-Bobot}

Hubungan panjang bobot ikan cakalang yang didaratkan di Larantuka diperoleh nilai $a=0.016$; nilai $\mathrm{b}=3,049$ dan nilai $\mathrm{R}^{2}=0,92$. Setelah di uji-t dapatkan $\mathrm{t}_{\text {hitung }}>$ $\mathrm{t}_{\text {tabel }}$ yaitu 13,26>1,97 hal ini berarti pola pertumbuhan bersifat alometrik positif yaitu pertambahan bobot lebih cepat dibanding pertambahan panjang. Hubungan panjang bobot ikan cakalang tersaji pada Gambar 2 .

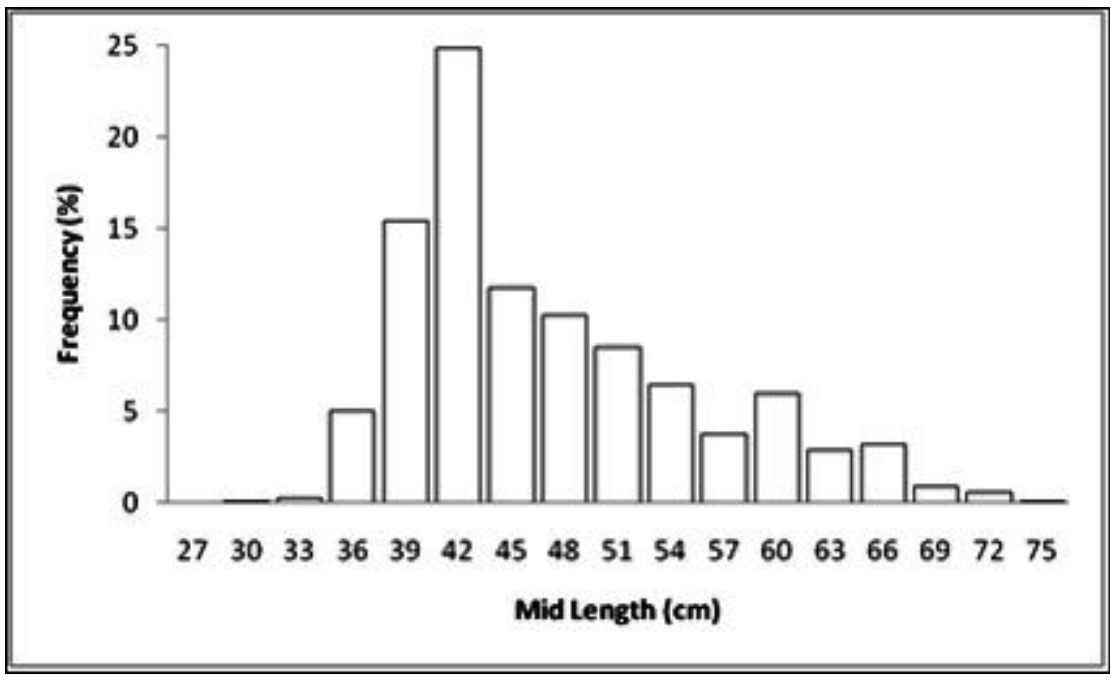

Gambar 1. Distribusi panjang cagak ikan cakalang yang tertangkap huhate di perairan Laut Flores dan sekitarnya pada bulan Februari-Oktober 2015.

Figure 1. Fork length distribution of Skipjack tuna caught by pole and line in Flores Sea and adjacent waters, February-October 2015.

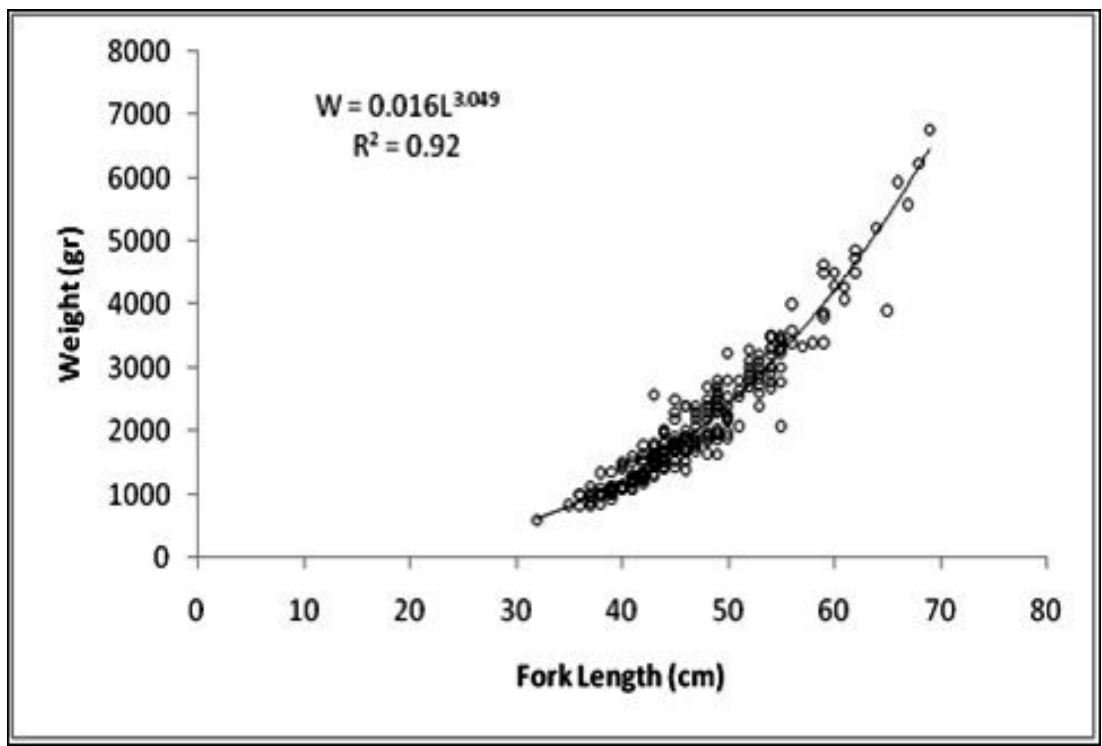

Gambar 2. Hubungan antara panjang cagak dan bobot cakalang.

Figure 2. Length-weight relationship of Skipjack tuna.

\section{Nisbah Kelamin}

Hasil pengamatan dari 235 ekor ikan cakalang yang didaratkan di Larantuka diperoleh. perbandingan jantan dan betina yaitu 1:1,14. Hasil uji rasio kelamin chi-square di dapatkan $\mathrm{X}_{\text {hit }}^{2}<\mathrm{X}_{\text {tab }}^{2}$ yaitu $0,98<3.84$ yaitu perbandingan ikan jantan dan betina di alam tidak berbeda nyata yaitu hampir berbanding $1: 1$. 


\section{Tingkat Kematangan Gonad (TKG)}

Hasil pengamatan tingkat kematangan gonad menunjukkan ikan jantan dan betina pada Juli dan Agustus hampir keseluruhan contoh ikan dalam kondisi TKG I dan TKG II yang merupakan ikan belum dewasa sedangkan

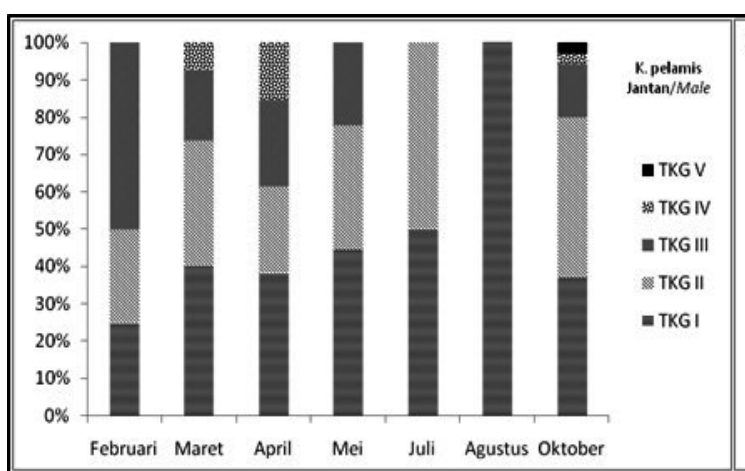

pada Maret, April, Oktober ditemukan ikan jantan dan betina dengan TKG IV yang merupakan indikasi ikan matang gonad dan siap memijah, sedangkan pada Oktober ditemukan ikan jantan dan betina dengan TKG V (Gambar 3) yang merupakan indikasi adanya ikan yang telah memijah.

Gambar 3. Tingkat kematangan gonad dan testis ikan cakalang.

Figure 3. Maturation of gonads and testes of skipjack tuna

\section{Indeks Kematangan Gonad (IKG)}

Gambar 4. Memperlihatkan fluktuasi nilai IKG antara Februari - Oktober. Berdasarkan hasil pengamatan diperoleh nilai IKG berkisar antara $0,07-2,5 \%$. Nilai ratarata IKG tertinggi terjadi pada Juli dan terendah pada Mei.
Dari perhitungan indeks kematangan gonad (IKG) musim pemijahan cakalang diduga terjadi dua kali dalam musim pemijahan. Periode pemijahan pertama diduga terjadi pada Maret, sedangkan periode kedua puncak musim pemijahan pada Agustus.

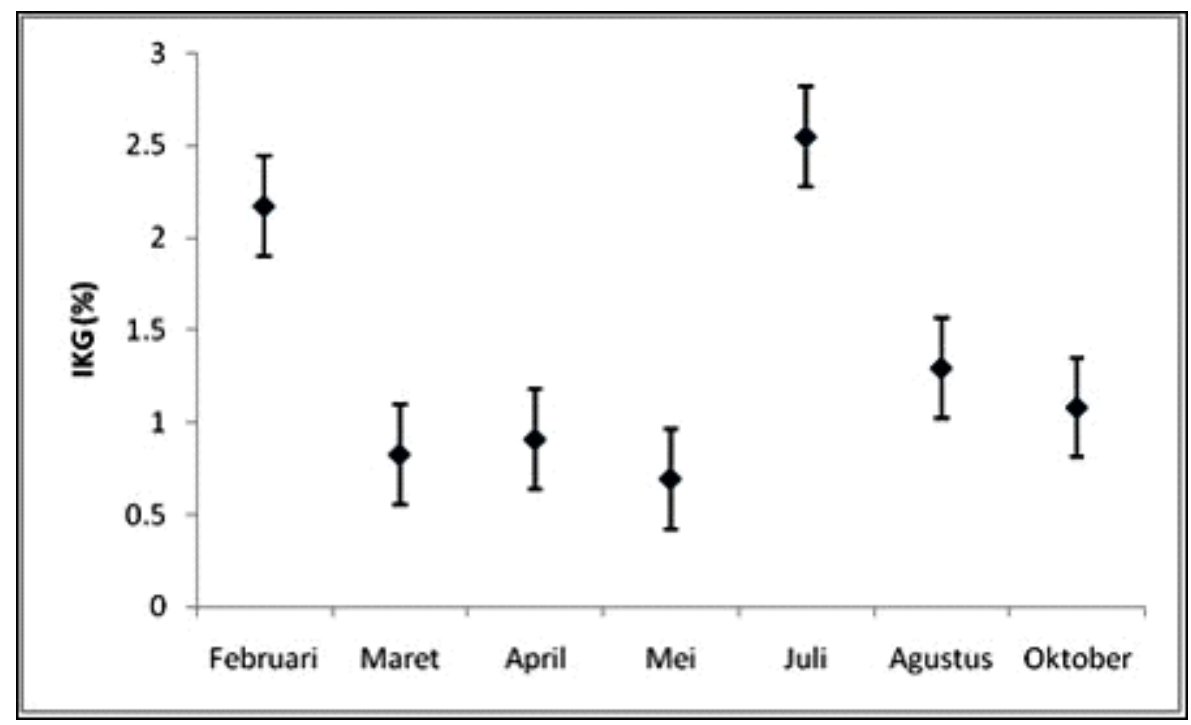

Gambar 4. Indeks kematangan gonad (IKG) ikan cakalang.

Figure 4. Gonadosomatic index (GSI)of skipjack tuna.

\section{Rata-rata PanjangPertama Kali Tertangkap (Lc) dan Panjang Pertama Kali Matang Gonad (Lm)}

Pendugaan rata-rata ukuran panjang pertama kali tertangkap (Lc) ikan cakalang diperoleh nilai 48,8 cmFL dan rata-rata ukuran panjang pertama kali matang gonad (Lm) adalah 41,1 cmFL (Gambar 5).

\section{Kebiasaan Makan}

Pengamatan isi lambung ikan cakalang diperoleh hasil $55,7 \%$ berupa ikan Sardinella spp. yang merupakan jenis ikan umpan pada perikanan pole and line, $34,7 \%$ berisi ikan teri (Stelophorus spp.), 7,9\% berisi ikan layang (Decapterus spp.), 0,9\% cumi-cumi (Loligo sp), 0,7\% berupa hancuran ikan dan sebesar $0,1 \%$, berupa Krustasea (Gambar 6). 


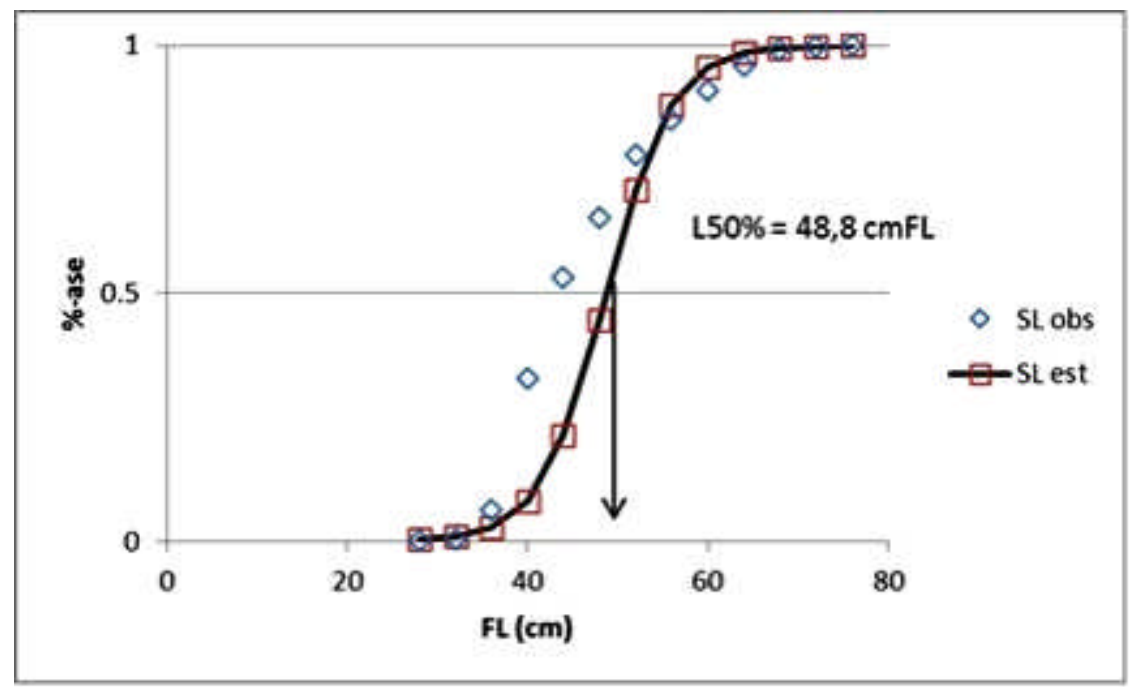

Gambar 5. Panjang rata-rata (50\% kumulatif) ikan cakalang.

Figure 5. Average length (50\% cumulatif) of skipjack tuna.

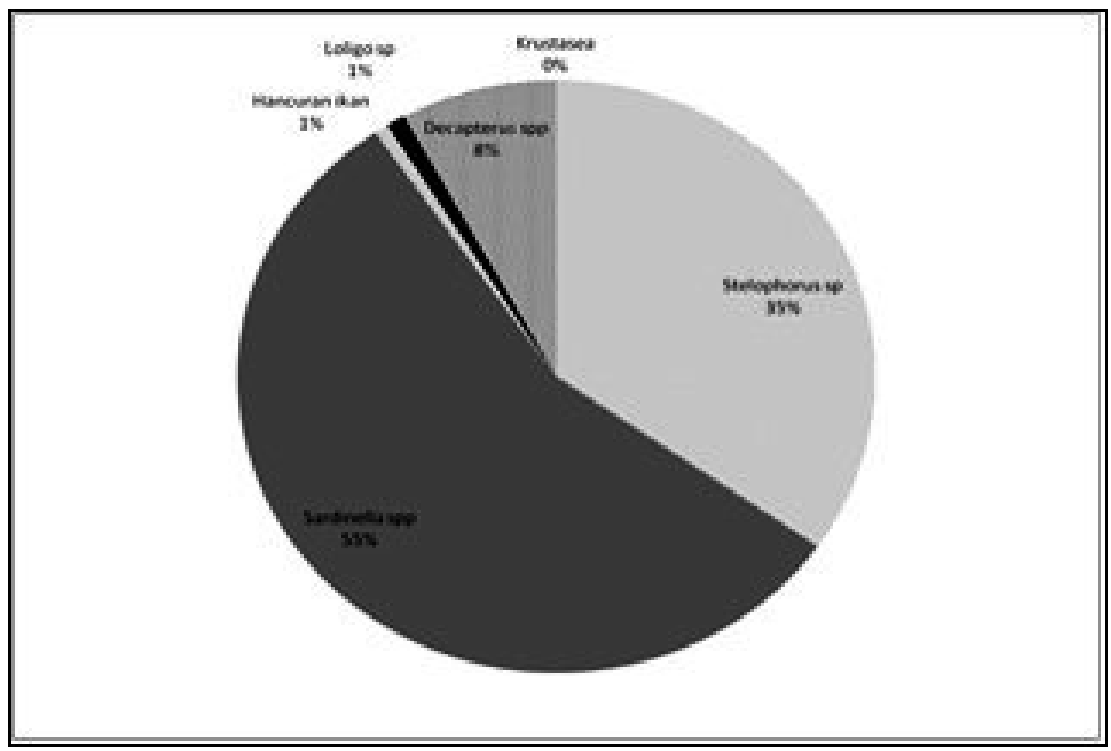

Gambar 6. Diagram indeks bagian terbesar ikan cakalang di Laut Flores.

Figure 6. Diagram index of preponderance of skipjack tuna in Flores Sea.

Kebiasaan makanan ikan cakalang setiap bulan disajikan pada Gambar 7. Pada Februari, Maret, April, Mei, kebiasaan makan ikan cakalang didominasi ikan teri sebesar 42,86\%; 58,5\%; 50,25\%; dan 91,4\%. Pada Juli, Agustus, dan Oktober jenis makanan yang ditemukan pada lambung ikan cakalang $100 \%$ berisikan ikan tembang. Ikan Layang yang ditemukan pada lambung ikan cakalang hanya pada Maret dan April, cumi-cumi hanya ditemukan pada Mei, sedangkan jenis krustasea hanya ditemukan pada Maret. 


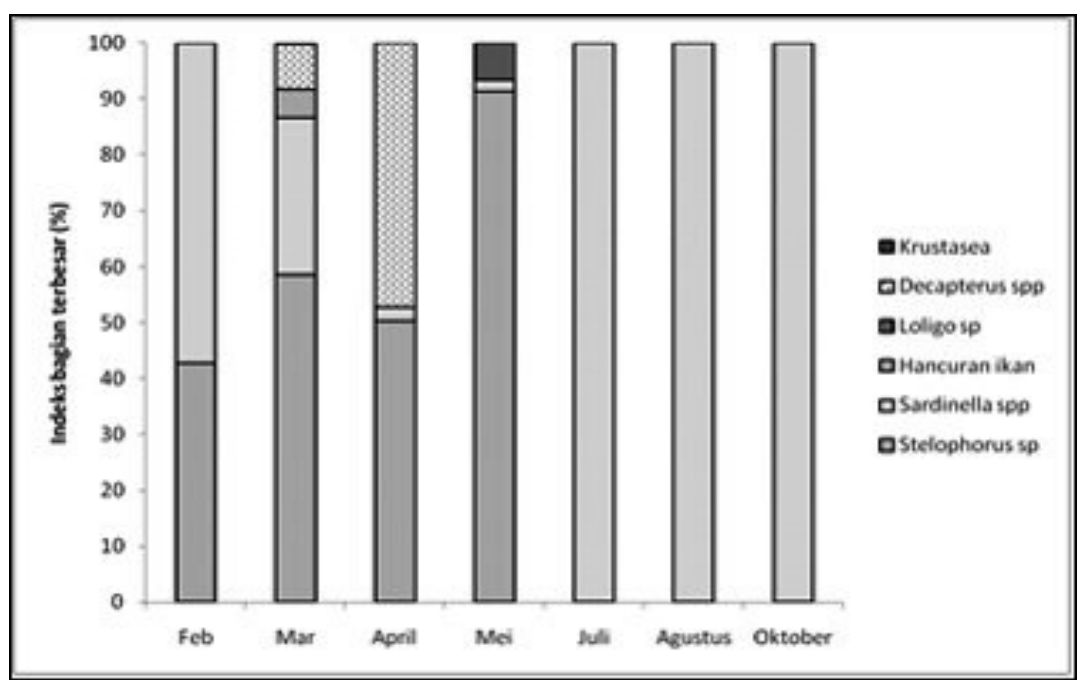

Gambar 7. Diagram indeks bagian terbesar ikan cakalang di perairan Laut Flores berdasarkan waktu pengamatan.

Figure 7. Diagram index of preponderance of skipjack tuna in Flores Sea based on the time of the study.

\section{Bahasan}

Kisaran panjang ikan cakalang di perairan Laut Flores dan sekitarnya yaitu $25-74 \mathrm{~cm}$ dengan pola pertumbuhan bersifat alometrik positif yang berarti bahwa pertumbuhan bobot individu lebih cepat dibandingkan dengan pertumbuhan panjang. Kondisi yang sama ditemukan juga pada cakalang yang tertangkap di perairan Pulau Seram Selatan dan Pulau Nusa Laut (Manik, 2007). Sedangkan hasil penelitian Jamal et al. (2011) menyebutkan pola pertumbuhan ikan cakalang yang tertangkap di perairan Teluk Bone bersifat isometrik. Faktor-faktor yang menyebabkan perbedaan pola pertumbuhan adalah perbedaan jumlah dan variasi ukuran ikan yang diamati. Perbedaan pola pertumbuhan menurut Al-Zibdah \& Odat (2007) disebabkan oleh perbedaan kesuburan perairan yang berhubungan dengan ketersediaan makanan. Apabila dikaitkan dengan ketersediaan makanan diduga makanan ikan cakalang di Laut Flores berlimpah. Effendie (2002) menyatakan bahwa makanan yang diambil akan mempengaruhi pertumbuhan, kematangan tiap individu dan keberhasilan hidupnya.

Nisbah kelamin ikan cakalang jantan terhadap betina secara keseluruhan sebagai 1:1,14 yang berarti jumlah tersebut dalam keaadaan seimbang atau individu jantan sama dengan individu betina. Menurut Effendi (1979) perbandingan jumlah individu jantan dan betina yang seimbang lebih memungkinkan terjadi pembuahan sel telur oleh spermatozoa hingga menjadi individu baru. Hasil uji chi square, nisbah kelamin jantan dan betina berdasarkan waktu penelitian tidak berbeda nyata pada taraf kepercayaan $95 \%\left(\mathrm{X}_{\text {hitung }}^{2}<\mathrm{X}_{\text {tabel }}^{2}\right)$ yang berarti bahwa nisbah kelamin ikan cakalang jantan dan betina seimbang (1=1). Hal ini diduga bahwa ikan cakalang di perairan Laut Flores berada dalam satu area pemijahan, sehingga peluang tertangkapnya sama.
Tingkat kematangan gonad adalah tahap tertentu perkembangan gonad sebelum dan sesudah ikan memijah, terutama untuk betina, sedangkan IKG merupakan nilai dalam \% sebagai hasil perbandingan berat gonad dan berat tubuh ikan (Rachmawati \& Hartati, 2017). Pertumbuhan IKG akan sama/proposional dengan TKG dan menjadi maksimal pada saat akan terjadi pemijahan (Effendie, 2002). Berdasarkan hasil penelitian pada Maret, April, Oktober ditemukan ikan jantan dan betina dengan TKG IV yang merupakan indikasi ikan matang gonad dan siap memijah, dan pada Oktober ditemukan juga ikan jantan dan betina dengan TKG V yang merupakan indikasi adanya ikan yang telah memijah. Hal tersebut menunjukkan bahwa kelompok ikan cakalang mengalami kematangan gonad yang tidak bersamaan sehingga diduga pemijahannya bersifat bertahap (partial spawner). Hal ini diperkuat dengan nilai IKG ikan betina tertinggi pada Februari dan Juli dan menurun pada Maret-Mei dan Agustus-Oktober. Nilai IKG maksimal menandakan ikan dalam tahap siap memijah dan mengalami penurunan seiring waktu setelah musim pemijahan. Berdasarkan hasil tersebut diduga awal musim pemijahan terjadi pada Februari-Maret dan Juli-Agustus. Hal ini serupa dengan pernyataan Wouthuyzen et al (1990) bahwa sifat pemijahan ikan cakalang secara bertahap tetapi puncak musim pemijahan ikan cakalang di Laut Banda terjadi pada Juni dan Desember. Musim pemijahan ikan dipengaruhi oleh faktor internal dan faktor eksternal. Faktor internal antara lain spesies, umur dan ketersediaan hormon, sedangkan faktor eksternal antara lain suhu perairan dan jenis makanan (Effendie, 2002).

Rata-rata ukuran pertama kali tertangkap $\left(\mathrm{L}_{50 \%}\right)$ sebesar 48,8 cmFL dan rata-rata ukuran pertama kali matang gonad $\left(\mathrm{L}_{\mathrm{m}}\right)$ sebesar $41,1 \mathrm{~cm}$. Hasil penelitian Jatmiko et al. (2015) di Samudera Hindia Bagian Timur dilaporkan bahwa ukuran pertama kali matang gonad cakalang adalah 42,9 cmFL dan ukuran panjang pertama kali matang gonad $\left(\mathrm{L}_{\mathrm{m}}\right)$ 
cakalang yang tertangkap di Samudera Hindia Bagian Barat, tepatnya di perairan Mauritius yaitu $43 \mathrm{cmFL}$ untuk betina dan $44 \mathrm{cmFL}$ untuk jantan (Norungee \& Kawol, 2011). Indian Ocean Tuna Commission (2013) melaporkan bahwa ukuran panjang pertama kali matang gonad $\left(\mathrm{L}_{\mathrm{m}}\right)$ cakalang adalah $44 \mathrm{~cm}$. Sedangkan ukuran panjang pertama kali matang gonad $\left(\mathrm{L}_{\mathrm{m}}\right)$ di Teluk Bone, Sulawesi Selatan yaitu 46,5 cmFL (Jamal, 2011). Dan ukuran panjang pertama kali matang gonad $\left(\mathrm{L}_{\mathrm{m}}\right)$ di Samudera Hindia Bagian Barat yaitu 37,8 cmFL (Grande et al., 2010). Menurut Udupa (1986), perbedaan hasil tersebut dapat terjadi karena dalam spesies yang sama juga terdapat kemungkinan mengalami ukuran panjang pertama kali matang gonad yang berbeda. Ukuran matang gonad pada penelitian ini lebih kecil dari hasil penelitian lainnya, hal ini dapat disebabkan karena tekanan penangkapan yang tinggi. Akibat tekanan penangkapan yang tinggi, untuk dapat mempertahanan keberlangsungan populasinya, ikan cakalang di Laut Flores mempercepat proses reproduksi yang di tandai dengan nilai Lm yang kecil di bandingkan perairan lain.

Menurut Lagler et al. (1962) dalam Larasati (2011) perbedaan ukuran pertama kali matang gonad dipengaruhi oleh beberapa faktor antara lain kebiasaan makan, umur, ukuran, dan kondisi fisiologis dari ikan tersebut. Menurut (Saputra et al., 2009. Widodo \& Suadi 2008), kondisi tangkap lebih (overfishing) secara biologi dapat digolongkan menjadi growth overfishing dan recruitment overfishing. Growth overfishing terjadi apabila hasil tangkapan didominasi oleh ikan-ikan kecil pada ukuran pertumbuhan, sedangkan recruitment overfishing terjadi apabila kegiatan eksploitasi lebih banyak menangkap ikan yang siap memijah (spawning stok) atau ikan dewasa matang gonad. Menurut Allen et al. (2013), recruitment overfishing merupakan kondisi lebih tangkap yang lebih parah dibandingkan dengan kondisi growth overfishing. Berdasarkan nilai laju eksploitasi, $\mathrm{L}_{50 \%}$ dan $\mathrm{Lm}$, diduga penangkapan ikan cakalang di perairan Laut Flores telah mengarah kepada kondisi recruitment overfishing $\left(\mathrm{L}_{\mathrm{m}}<\right.$ $\mathrm{L}_{50 \%}$ ). Kondisi seperti ini sangat membahayakan keberadaan stok sumberdaya ikan cakalang, karena secara substansial merusak produktivitas stok ikan dan menyebabkan runtuhnya stok sumberdaya ikan. Beberapa upaya yang direkomendasikan untuk mencegah terjadinya recruitment overfihing adalah proteksi terhadap penangkapan sejumlah stok induk yang memadai.

Hasil pengamatan terhadap isi lambung ikan cakalang yang tertangkap di perairan Laut Flores terdiri atas ikan pelagis kecil didominasi dengan ikan tembang, ikan teri, ikan layang, cumi-cumi, dan krustasea. Berdasarkan nilai IRP setiap jenis makanan bervariasi pada tiap bulan, dapat diduga bahwa ikan cakalang tidak mempunyai preferensi dalam kebiasaan makan (feeding habit). Hal ini sesuai dengan keterangan HOTTA \& OGAWA dalam HIDA
(1973), bahwa cakalang termasuk tuna tidak selektif di dalam kebiasaan makannya, karena itu akan memakan apa saja yang dijumpai bahkan dapat memakan jenis-jenisnya sendiri.

Selain itu, hampir setiap bulan isi lambung ikan cakalang dijumpai ikan tembang dan ikan teri, hal ini menandakan di perairan Laut Flores keberadaan ikan pelagis kecil khususnya ikan tembang dan ikan teri melimpah. Hasil penelitian Wouthuyzen et al. (1990) menyatakan bahwa makanan alami utama ikan cakalang yang tertangkap di perairan sebelah selatan Pulau Seram dan sekitar Pulau Nusa Laut, laut Banda ialah krustasea, moluska dan ikan terutama pada tahap juvenil.

Manik (2007) menjelaskan Ada tiga komponen utama yang merupakan makanan ikan cakalang yaitu ikan yang terdiri dari ikan umpan (Stolephorus spp), krustasea dan moluska. Sedangkan Mardijah (2008) menjelaskan bahwa komposisi makanan ikan cakalang yang tertangkap di perairan Laut Sulawesi berubah-ubah di mana di dalam isi lambungnya didapatkan berbagai jenis ikan pelagis kecil seperti ikan kembung (Rastrelliger sp.), ikan layang malalugis (Decapterus macarellus), ikan sardine (Clupea sp.) dan kepiting (Portunidae sp.) di mana makanan yang dominan adalah ikan layang $(57 \%)$.

\section{KESIMPULAN}

Pola pertumbuhan ikan cakalang (Katsuwonus pelamis) di perairan laut Flores dan sekitarnya bersifat alometrik positif. Ikan cakalang mempunyai pemijahan bertahap (partial spawner), diduga awal puncak musim pemijahan (spent) berlangsung pada Februari-Maret dan Juli-Agustus. Isi lambung ikan cakalang terdiri dari ikan tembang sebagai makanan utamanya. Kondisi perikanan ikan cakalang di Larantuka diduga mengarah pada recruitment overfishing dan perlu adanya pembatasan pada penangkapan sejumlah stok induk. Jika tidak dikelola dengan baik dan benar dapat membahayakan keberadaan stok sumberdaya ikan cakalang.

\section{PERSANTUNAN}

Tulisan ini merupakan kontribusi dari hasil penelitian aspek biologi, tingkat pemanfaatan dan optimasi pemanfaatan sumberdaya ikan pelagis besar di WPP 714 T.A 2015 di Balai Riset Perikanan Laut, Jakarta.

\section{DAFTAR PUSTAKA}

Afonso-Dias, I., Reis, C., \& Andrade, P. (2005). Reproductiveaspects of Microchirus azevia (Risso, 1810) (Pisces: Soleidae) from the south coast of Portugal. Scientia Marina. 69(2), 275-283. 
Akbar, M. A., Suryanto., \& Triharyuni, S. (2016). Analisis perikanan huhate di perairan Larantuka, Flores. J. Lit. Perikan. Ind. 22(2), 115-122. doi: http://dx.doi.org/ 10.15578/jppi. 22.2.2016.115-122

Allen, M., Hanson, M. J., Ahrends, R., \& Arlinghaus, R. (2013). Dynamic angling effort influences the value of minimum-length limits to prevent recruitment overfishing. Fisheries Management and Ecology, 20, 247-257.

Al-Zibdah, M. \& Odat, N. (2007). Fishery status, growth, reproduction biology and feeding habit of two scombrid fish from the Gulf of Aqaba Red Sea. Lebanon Science Journal, 8(2), 3-16.

Anonimus. (2015). Laporan hasil penelitian karakteristik biologi perikanan habitat sumberdaya dan potensi produksi sumberday ikan di WPP 714 (Laut Banda dan Teluk Tolo). Balai Penelitian Perikanan Laut (Tidak Dipublikasikan), 2015.

Anonimus. (2015). Statistik perikanan tangkap di laut menurut wilayah pengelolaan perikanan Negara Republik Indonesia (WPP-NRI) 2005-2014. Kementerian Kelautan dan Perikanan, Direktorat Jenderal Perikanan Tangkap, 2015.

Bal, D.V., \& Rao, K.V. (1984). Marine Fisheries (p. 491). New Delhi: Tata McGraw-Hill Publishing Company.

Collette, B.B., \& Nauen, C.E. (1983). FAO species catalogue. Vol. 2. Scombrids of the world. An annotated and illustrated catalogue of tunas, mackerels, bonitos, and related species known to date. Rome: FAO. FAO Fish. Synop, 125(2).

Diniah, M.A., Yahya, S., Pujiyati., Parwinia, S., Effendy., Hatta, M., Sabri, M., Rusyadi., \& Farhan, A. (2001). Pemanfaatan sumber daya tuna (Thunnus) dan cakalang (Katsuwonus pelamis) secara terpadu. Makalah Falsafah Sains. Program Pasca Sarjana Institut Pertanian Bogor. Bogor.

Effendie, M. I. (1979). Metode biologi perikanan (p. 112). Bogor: Yayasan Dewi Sri.

Effendie, M. I. (2002). Biologi perikanan (p.163). Penerbit Yayasan Pustaka Nusatama. Yogyakarta.

Grande, M., Murua, I., Zudaire., \& Korta, M. (2010). Spawning activity and batch fecundity of skipjack, Katsuwonus pelamis, in the Western Indian Ocean. IOTC-2010-WPTT-47: 28 pp. (Unpublished).
Holden, M. J., \& Raitt D. F. S. (Eds.). (1974). Manual of fisheries sciences. Part 2. Methods of resource investigation and their application (p. 214). FAO Fish, Tech. Pap. (115). Rev. 1.

Indian Ocean Tuna Commission. (2013). Report of the Fifteenth Session of the IOTC Working Party on Tropical Tunas. San Sebastian, Spain, 23-28 Oktober 2013. p. 93.

Jamal, M. (2011). Pemanfaatan data biologi ikan cakalang (Katsuwonus pelamis) dalam rangka pengelolaan perikanan bertanggung jawab di perairan Teluk Bone. Jurnal Natur Indonesia. 14(1), 107-113.

Jatmiko, I., Hartaty, H., \& Bahtiar, A. (2015). Biologi reproduksi ikan cakalang (Katsuwonus pelamis) di Samudera Hindia bagian Timur. BAWAL. 7(2), 87-94. doi: http://dx.doi.org/10/15578/bawal.7.2.2015.87-94

Larasati, D.A. (2011). Kajian reproduksi biologi ikan kembung perempuan (Rastrelliger brachysoma, Bleeker 1851) di perairan Teluk Jakarta, Jakarta Utara. Skripsi. Fakultas Perikanan dan Ilmu Kelautan Institut Pertanian Bogor. Bogor.

Manik, N. (2007). Beberapa aspek biologi ikan cakalang (Katsuwonus pelamis) di Perairan Sekitar Pulau Seram Selatan dan Pulau Nusa Laut. Jurnal Oseanologi dan Limnologi Indonesia, 33, 17 - 25.

Mardlijah, S. (2008). Analisis isi lambung ikan cakalang (Katsuwonus pelamis) dan Ikan Madidihang (Thunnus albacares) yang didaratkan di Bitung, Sulawesi Utara. J. Lit. Perikan. Ind, 14 (2), 227-235. doi: http://dx. doi.org/10.15578/jppi.14.2.2008.227-235.

Norungee, D. \& Kawol, D. (2011). Macroscopic study on some aspects of the reproductive biology of skipjack tuna (Katsuwonus pelamis) in the Western Indian Ocean. In: Proceeding Working Party on Tropical Tunas of the IOTC 2011.

Rachmawati, P.F., \& Hartati, S. T. (2017). Aspek biologi ikan layur (Lepturacanthus savala; Cuvier, 1829) di perairan Pangandaran, Jawa Barat. BAWAL. 9(2), 133143. doi: http://dx.doi.org/10.15578/bawal.9.2.2017.133143.

Saputra, S.W. (2005). Dinamika populasi udang jari (Metapenaeus elegans de man) dan pengelolaannya di Laguna Segara Anakan Kabupaten Cilacap Jawa Tengah. Disertasi. Program Pasca Sarjana Institut Pertanian Bogor. 
Saputra, S.W., Soedarsono, P., \& Sulistyawati, G.A. (2009). Beberapa aspek biologi ikan kuniran (Upeneus spp.) di Perairan Demak. Jurnal Saintek Perikanan, 5(1), 1-6.

Sparre, P., \& Venema, S.C. (1999). Introduksi pengkajian stok ikan tropis. Badan Penelitian dan Pengembangan Perikanan. Terjemahan dari Introduction to tropical fish stock assessment. FAO Fish Tech. Paper 306(1), p. 376.

Udupa, K.S. (1986). Statisticalmethod of estimating the size at first maturity in fishes. ICLARM, Metro Manila, Fishbyte, 4 (2), 8-10.
Widodo, J., \& Suadi. (2008). Pengelolaan sumberdaya pengelolaan laut (p. 252). Yogyakarta: Gadjah Mada University Press.

Wouthuyzen, S., Peristiwady, T., Manik, N., Djoko, S., \& Hukom, F.D. (1990). Makanan dan aspek reproduksi ikan cakalang (Katsuwonus pelamis) di Laut Banda, Suatu Studi Perbandingan. Perairan Maluku dan Sekitarnya, Balai Penelitian dan Pengembangan Sumberdaya Laut Pusat Penelitian dan Pengembangan Osenaologi Lembaga Ilmu Pengetahuan Indonesia, Ambon. 